\title{
Cloning and functional characterization of a fructan 1-exohydrolase (1-FEH) in edible burdock (Arctium lappa L.)
}

\author{
Keiji Ueno', Yojiro Ishiguro", Midori Yoshida², Shuichi Onodera ${ }^{1}$ and Norio Shiomi ${ }^{*}$
}

\begin{abstract}
Background: We have previously reported on the variation of total fructooligosaccharides (FOS), total inulooligosaccharides (IOS) and inulin in the roots of burdock stored at different temperatures. During storage at $0^{\circ} \mathrm{C}$, an increase of FOS as a result of the hydrolysis of inulin was observed. Moreover, we suggested that an increase of IOS would likely be due to the synthesis of the IOS by fructosyltransfer from 1-kestose to accumulated fructose and elongated fructose oligomers which can act as acceptors for fructan:fructan 1-fructosyltransferase (1-FFT). However, enzymes such as inulinase or fructan 1-exohydorolase (1-FEH) involved in inulin degradation in burdock roots are still not known. Here, we report the isolation and functional analysis of a gene encoding burdock 1-FEH.

Results: A CDNA, named aleh1, was obtained by the RACE method following PCR with degenerate primers designed based on amino-acid sequences of FEHs from other plants. The aleh1 encoded a polypeptide of 581 amino acids. The relative molecular mass and isoelectric point ( $(p)$ of the deduced polypeptide were calculated to be 65,666 and 4.86. A recombinant protein of aleh1 was produced in Pichia pastoris, and was purified by ion exchange chromatography with DEAE-Sepharose CL-6B, hydrophobic chromatography with Toyopearl HW55S and gel filtration chromatography with Toyopearl HW55S. Purified recombinant protein showed hydrolyzing activity against $\beta-2,1$ type fructans such as 1-kestose, nystose, fructosylnystose and inulin. On the other hand, sucrose, neokestose, 6-kestose and high DP levan were poor substrates.

The purified recombinant protein released fructose from sugars extracted from burdock roots. These results indicated that aleh1 encoded 1-FEH.
\end{abstract}

\section{Background}

Fructans (polyfructosylsucrose) are important storage carbohydrates in plants such as Poaceae (e.g. wheat and barley), Asteraceae (e.g. burdock, chicory and Jerusalem artichoke), and Liliaceae (e.g. onion and asparagus) [1,2]. Inulin-type fructan $\left[1^{\mathrm{F}}(1-\beta \text {-D-fructofuranosyl })_{m}\right.$ sucrose $]$, which is a $\beta-2,1$ linked fructose-oligomer or -polymer terminated by glucose, is mainly accumulated in Asteraceae plants (Figure 1). The inulin-type fuctan is synthesized from sucrose by sucrose:sucrose 1-fructosyltransferase

\footnotetext{
* Correspondence: n-shiomi@rakuno.ac.jp

'Department of Food and Nutrition Sciences, Graduate School of Dairy Science Research, Rakuno Gakuen University, 582 Bunkyodai Midorimachi, Ebetsu, 069-8501, Japan

Full list of author information is available at the end of the article
}

(1-SST, EC 2.4.1.99) and fructan:fructan 1-fructosyltransferase (1-FFT, EC 2.4.1.100). 1-SST synthesizes 1-kestose (1- $\beta$-D-fructofuranosylsucrose, 1-kestotriose), an inulintype trisaccharide, from two molecules of sucrose by fructosyltransfer [3-6]. 1-FFT elongates fructose chain of inulin-type fructans by fructosyltransfer from 1-kestose to another 1-kestose or fructan [3,7-9]. Levan-type fructan is a $\beta-2,6$ linked fructose-oligomer or -polymer terminated by glucose. Graminan-type fructan is a $\beta-2,1$ and $\beta-2,6$ linked fructose-oligomer or -polymer terminated by glucose. These fructans are mainly found in Poaceae [10-12]. Inulin neoseries -type fructan $\left[1^{\mathrm{F}}(1-\beta-\mathrm{D}\right.$-fructofuranosyl) $m^{-6^{\mathrm{G}}}(1-\beta \text {-D-fructofuranosyl })_{n}$ sucrose], which has a $\beta-2,1$ linked fructosyl residue(s) on the carbon- 6 of terminal glucosyl residue of inulin-type fructan is mainly accumulated in Liliaceae [13-15]. 


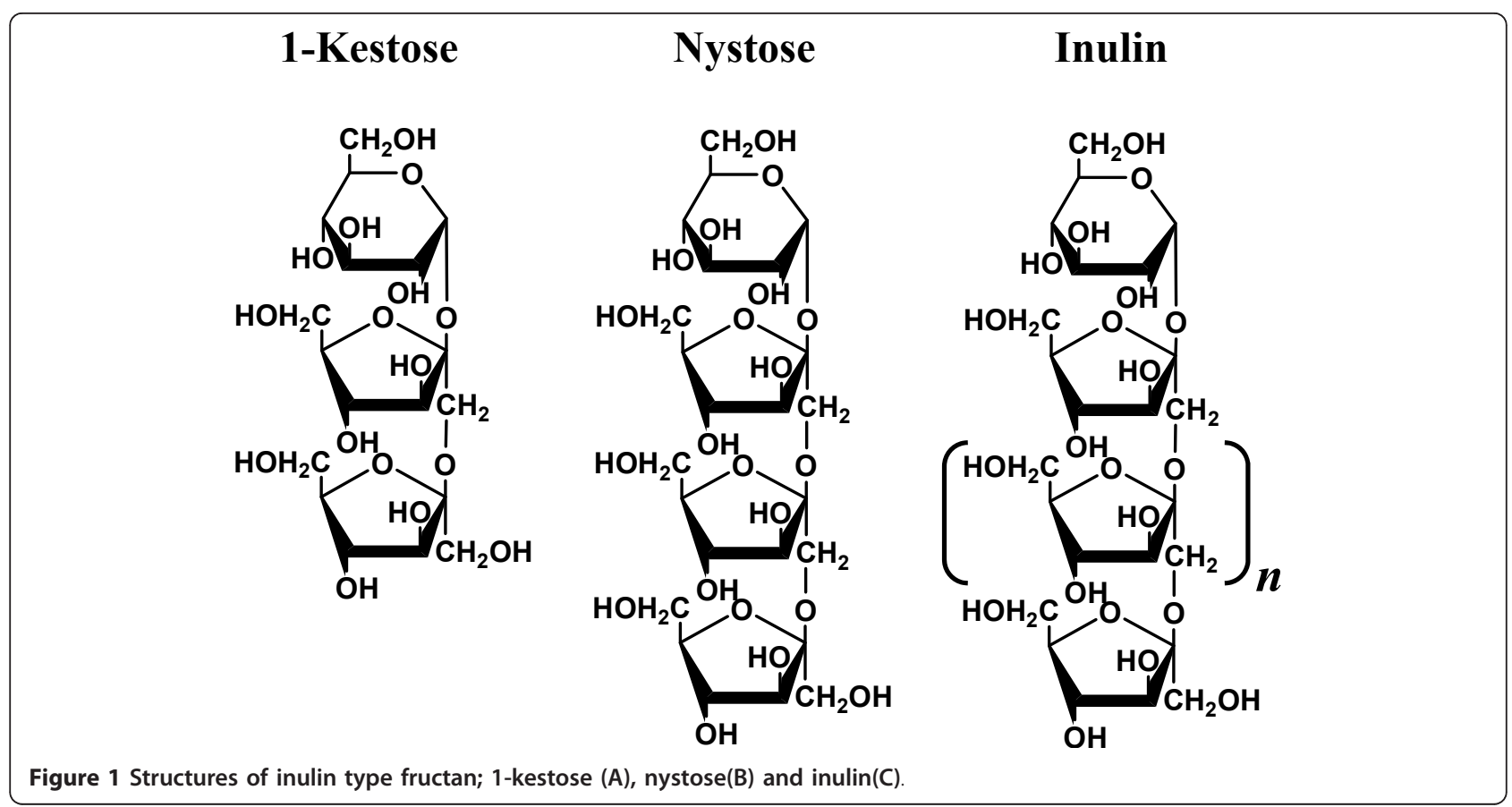

Fructan exohydrolases (FEHs) participate in the degradation of plant fructan, and three different types of FEHs such as 1-FEH, 6-FEH and 6\&1-FEH have been reported [16-19]. Plant 1-FEH preferentially hydrolyzes the $\beta-2,1$ linkage of terminal fructosyl residue of fructan [16-18]. Plant 6-FEH preferentially hydrolyzes the $\beta-2,6$ linkage of terminal fructosyl residue of fructan [19]. Plant $6 \& 1-\mathrm{FEH}$ can degrade both $\beta-2,1$ and $\beta-2,6$ linkages at the terminal residue [20]. These FEHs are distinguished from invertase ( $\beta$-fructofuranosidase, EC 3. 2. 1. 26) because the enzymes do not hydrolyze sucrose [21].

Edible burdock (Arctium lappa L.) roots are eaten in Japan as it contains much dietary fiber. Edible burdock belongs to the Asteraceae and is known for high content of inulin-type fructan. We have previously reported that an inulin-type fructan accumulated in roots of edible burdock, and we found a cDNA encoding 1-FFT involved in the synthesis of inulin-type fructan from edible burdock [22]. Furthermore, inulooligosaccharides (IOS) as well as inulin-type fructan were detected in burdock roots stored under soil for six month in winter [23], and we assessed the variation of these oligosaccharides and their related metabolizing enzymes stored at different temperatures $[24,25]$. The IOS and FOS increased progressively during storage at low temperatures [24]. The increase of FOS would likely be due to the hydrolysis of inulin or synthesis by 1-FFT from low DP fructan. One of the reasons for an increase in the IOS was thought to be its biosynthesis by 1-FFT which catalyzes the fructosyltransfer from low DP fructan or inulin to fructose produced by degradation of inulin.
However, the degradation of inulin and fructooligosacchrides in edible burdock was not established. In this study, we demonstrate cloning and functional analysis of a 1-FEH involved in the degradation of an inulin-type fructan of edible burdock.

\section{Results and Discussion}

Molecular cloning of edible burdock 1-FEH

Edible burdock 1-FEH cDNA was obtained by the RACE method following PCR using degenerate primers based on the amino-acid sequences of FEHs from other plants (Table 1). A full length cDNA named aleh1 consisted of 2,063 bp and contained an open reading frame (ORF) of $1746 \mathrm{bp}$ and poly (A) sequence at the 3 ' end. The ORF

Table 1 PCR primers for cDNA cloning and construction of expression vector.

\begin{tabular}{lc}
\hline Primer name & DNA sequence $\left(\mathbf{5}^{\prime}\right.$ to $\mathbf{3}^{\prime}$ ) \\
\hline Dp-A & ACIGSITWYCAYTTYCARCC \\
Dp-C & YTCYTCITYNGGCCAYTG* \\
Gene Racer 5'primer & CGACTGGAGCACGAGGACACTGA \\
5Ra-EHa & CACCAGGTCGTATGATACGGCATGCCCCC \\
Gene Racer 3'primer & GCTGTCAACGATACGCTACGTAACG \\
3Ra-EHa & GCGGCAGTGTGATGCACGTGATGAAGGCTG \\
EHa-FwA & ACTCTCGTCACCCAAAG \\
EHa-Rvl & AGAGCTATCAAACGAACTCT \\
EHa-ECoRI.Q34 & AGGAATTCAGCGGTCCAACAACCGTA** \\
EHa-Xbal & GTTCTAGAGCTGCACTTTTACGGTCTG** \\
\hline
\end{tabular}

${ }^{*} N=(A, T, G, C), R=(A, C), S=(C, G), Y=(C, T), W=(A, T), I=$ inosine. **Bold characters indicate the sequence of restriction sites. 
AlEH1

Chi_1-FEH2

Vh $1-\mathrm{FEH}$

Chi__1-FEH1

AlEH1

Chi 1-FEH2

Vh $\overline{1}-\mathrm{FEH}$

Chi__1-FEH1

AlEH1

Chi_1-EEH2

Vh 1-FEH

Chi__1-FEH1

AlEH1

Chi_1-EEH2

Vh_ $1-\mathrm{FEH}$

Chi__1-FEH1

AlEH1

Chi 1-EEH2

Vh $1-\mathrm{FEH}$

Chì_1-FEH1

AlEH1

Chi 1-FEH2

Vh $1-\mathrm{FEH}$

Chi__1-EEH1

AlEH1

Chi_1-EEH2

Vh $\overline{1}-\mathrm{FEH}$

Chi__1-FEH1

AlEH1

Chi 1-EEH2

Vh $1-\mathrm{FEH}$

Chi__-FEH1

AlEH1

Chi 1-FEH2

Vh $1-\mathrm{FEH}$

Chi__1-EEH1

\section{$\downarrow$}

---MKSLVSILALCFLGIIG----TEAAGRNLKDVISLPSQRFQQPYRTGYHFQPPNNWMNDPNGPMLYE --MKKS LS SF IVLCFLVI I LETGRVKATSRNLNDVIMLANQQ IEQPYRTGYHFQPP SNWMNDPNGPMLYQ --MNKPLSSFLTLCLLVLVHGPGHFDATRQNLKDI I S LPTQI IEQPYRTGYHFQPP SNWMNDPNGPMLYN MCSERRVKEILGIWVLSLCL------VWVQNGVGVHSSSPTEESQPYRTGFHFQP PKNWINDPNGPMYFN

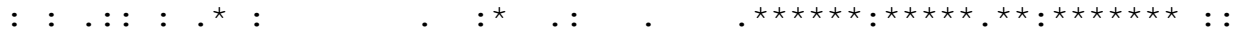
GVYHFFYQYNPYAATFGDVIIWGHAVSYDLVNWIHLDPAIYPTHEADSKSCWSGSATILPGNIPMMLYTG GVYHFFYQYNPYAATFGDVIIWGHAVSYDLVNWIHLDPAIYPTQEADSKSCWSGSATILPGNIPAMLYTG GVYHFFYQYNPYAATFGDVIVWGHAVSYDLVNW IHLDPAIYPTHEADAKSCWSGSATILPGNIPAMLYTG GVYHLFYQYNPYGPLWGN-ISWGHS ISYDLVNWFLLEPALSPKEPYDINGCLSGSATILPGPRPI ILYTG

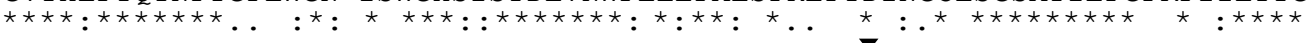
SDSKSRQVQDLAWPKNLSDPFLREWVKYEHNPI I TPPDGVKDDCFRDPSTAWKGPDGLWRMVVGADRDNN SDSKSRQVQDLAWPKNLSDPFLREWVKHPKNPLITPPEGVKDDCFRDP STAWLGPDGVWRIVVGGDRDNN SDSHSRQVQDLAWPKNRSDPFLREWVKYTGNPLITAPEGVNDDCFRDPSTAWQGPDGVWRIVVGADRDNN QDVNNSQVQNLAFPKNLSDPLLKEWIKWSGNPLLTPVDDIKAGQFRDP STAWMGPDGKWRIVIGSEIDGH

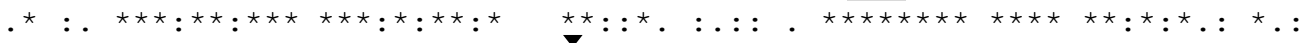
GMAYVYQSTDFKTWTRYDHPLSSAEATGTWECPDFYPVPLNSTNGLDTSTYSGSVMHVMKAGFQGHDWYT GMAFLYQSTDFVNWKRYDQPLSSADATGTWECPDFYPVPLNSTNGLDTSVYGGSVRHVMKAGFEGHDWYT GMAFLYQSTDFVNWKRYEQPLS SADLTGTWECPDVYPVPLNSTNGLDTSVYGGXVKHVMKAGFGGHDWYT GTALLYRSTNGTKWIRSKKPLHFSSKTGMWECPDFYPVTNGDKKGLDTSVQGNNTLHVLKVSFNSREYYV

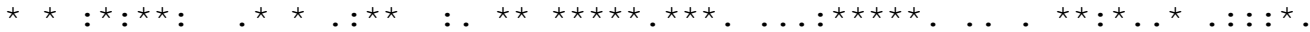
IGTYSPDRENFLPQNGLRLSGSNLDLRYDYGNFYASKSFFDDSKNRRVLWGWI PESDSQEDDIEKGWAGL IGTYSPDRENFLPQNGLSLTGSTLDLRYDYGQFYASKSFFDDAKNRRVLWAWVPETDSQADDIEKGWAGL IGTYTPDRENFLPQNEVDRKYYGPEVR--YGNFYASKSFFDDAKNRRVLWGWIPESDSQEDDIQKGWAGL IGTYDP I KDKFSVVTN-DFMVSNTQFQYDYGRYYASKSFYDSVNQRRVIWGWVNEGDSESDAVKKGWSGL

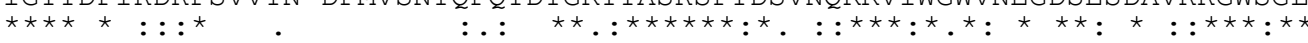
QSFPRAVWIDRSGSQLIQWPVEEIETLRQNEVKLENKKLDSASPVYEIQGITASQADVTISFKLEGLTIE QSFPRALWIDRNGKQLIQWPVEEIEELRQNQVNLQNKNLKPGS-VLEIHGIAASQADVTISFKLEGL--K QSFPRALWIDRSGMQLIQWPVDEIEKLRLNEVNLQNKNLKPGS-VLEIQGITASQADVTISEKLENL--K QSFPRS IWLSNNRKQLVQWPVDEI LKLRTKQVNITNRELAAGE-LLKI PS ITASQADVEVSFSLTNL--T

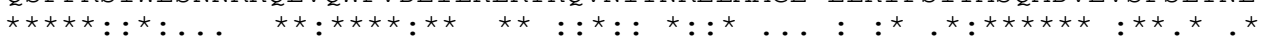
DTEHLDTTSADPQALCTERGASSKGAFGPFGLLAMASKDREEQTAIFFRVFYDQKIKRYSVLMCSDLSRS EAEVLDTTLVDPQALCNERGASSRGALGPFGLLAMASKDLKEQSAIFFRVFQNQ-LGRYSVLMCSDLSRS EAEVLDTSLTDPQALCNERGASSQGVFGPFGLLAMASKDLKEQTAIFFRVFQNQ-NGRYSVLMCSDLSRS EIELIDSEVVDPQLLCAQKNVS ISGKFGPFGMLILASKNLTEQTAVFFRVFKGP--NKFLVLMCSDQSRS

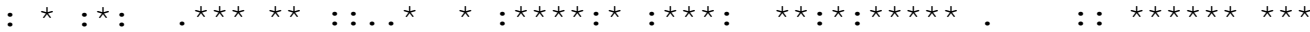
TVRSNIDTTSYGAFVDIDLQNNNEISLRNLIDHSIIESFGEEGKTCITSRVYPKFAYNEDAHLFAFNNGT TVRSNIDTTSYGAFVDIDPRSE-EISLRNLIDHSI IESFGAGGKTCITSRIYPKFVNNEEAHLFVFNNGT TVKSNIDTTSFGAFVDINPRYN-EISLRNLIDHSI IESFGAEGKTCITSRVYPKFVNYEEAHLYAFNNGT SIAQEVDKS IYGAFLDLDPLHE-KIPLRSLIDHSIVESFGGEGIACITSRVYPKLA INEQAELYVFNNGT

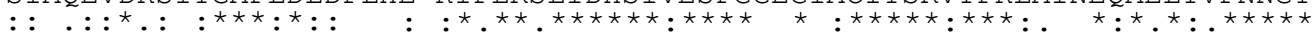
RSVTISKMSAWSMKDAEFVIDQTVKSAA---

QNVKISEMSAWSMKNAKFVVDQSVKSAA---

QSVKISRMSAWSMKSAEFI IDQTVKSATMEK

QSVTMSTLNAWSMKRAQIVPIG---------

$\therefore{ }^{\star} .:^{\star}: .^{\star \star \star \star \star *}{ }^{\star}::$ :

Figure 2 Comparison of deduced amino-acid sequence of aleh1 with those of other Asteraceous 1-FEH. AlEH1, deduced amino-acid sequence of aleh1 (AB611034); Chi_1-FEH2, Cichorium intybus 1-FEH lla (AJ295033); Vh_1-FEH, Vernonia herbacea (AM231149) and Chi_1-FEH1, Cichorium intybus 1-FEH I (AJ242538) are aligned. Potential N-glycosylation sites in the sequence are underlined. DPNG, RDP and EC motifs are shaded in gray. The three carboxylic acids that are thought to be crucial for enzyme activity are indicated by black inverted triangle. Consensus line: asterisks $\left(^{*}\right)$ indicated identical residues; colons (:) indicated conserved substitutions; and periods (.) indicated semi-conserved substitutions. Putative N-terminal amino acid of AlEH1 is indicated with an arrow.

encoded a polypeptide of 581-amino acids (Figure 2). The deduced polypeptide was denoted as AlEH1. The primary sequence of AlEH1 exhibits high identity with that of chicory 1-FEH IIa/IIb (82\%) and Vernonia herbacea 1 -FEH (80\%), but only $53 \%$ identity with chicory
1-FEH I. Phylogenetic tree analysis based on the deduced amino acid sequences shows that the AlEH1 is present in group of cell wall invertases as well as other FEHs (data not shown) [16-20]. The molecular mass and $\mathrm{p} I$ of AlEH1 was calculated to be 65,666 and 4.86, 
respectively. The amino acid sequence contains three putative $N$-glycosylation sites $(\mathrm{N}-\mathrm{X}-\mathrm{S} / \mathrm{T})$. The AlEH1 contains three regions of amino acid sequences such as NDPN ( $\beta$-fructosidase motif), RDP (RDP motif) and EC (catalytic site). These regions are conserved in the glycoside hydrolase family 32 (GH32) [26], and the role of the conserved domains of GH32 was identified by Reddy and Maley and by Meng and Fütterer [27-29].

\section{Heterologous expression and purification of recombinant protein}

A heterologous expression system using Pichia pastoris is very suitable for producing the translation product from the genes of plant fructosyltransferases and invertases [30]. $P$. pastoris does not produce any fructosyltransferases and invertases, background activities of these enzymes were not detected in the culture medium of $P$. pastoris. A recombinant protein was obtained by expression of aleh1 in $P$. pastoris. From the enzyme assay with 1-kestose as a substrate, hydrolytic activity was detected in the culture medium of $P$. pastoris. The enzyme was purified from the culture medium by ion exchange chromatography with DEAE-Sepharose CL-6B, and hydrophobic and gel filtration chromatographies using Toyopearl HW55S.

The active fraction separated by gel filtration chromatography showed a single band of protein, and the molecular mass was estimated to be about 80,000 by SDS-PAGE. On the other hand, the molecular mass of the purified enzyme deglycosylated by peptide: $\mathrm{N}$-glycosidase F (PNGase F) was estimated to be about 65,000 in agreement with the calculated mass of the recombinant protein (Figure 3). Purification procedures used to obtain the recombinant protein are summarized in Table 2. Specific 1-FEH activity of the recombinant protein was $73.4 \mathrm{U} / \mathrm{mg}$ of protein.

\section{General properties of the enzyme}

Optimum $\mathrm{pH}$ of the recombinant AlEH1 was 5.8. The enzyme was stable in the range of $\mathrm{pH} 5.5-9.0$ at $4^{\circ} \mathrm{C}$ for $24 \mathrm{~h}$ (residual activity more than $80 \%$ ). The enzyme was stable up to $40^{\circ} \mathrm{C}$ (residual activity more than 90\%), and inactivated at $50^{\circ} \mathrm{C}$ (Table 3 ) in pre-incubation for $15 \mathrm{~min}$.

To confirm the cleavage type of the recombinant enzyme, the enzyme was incubated with $100 \mathrm{mM}$ sucrose, 1-kestose, nystose and $5 \%$ inulin at $30^{\circ} \mathrm{C}$ for 0,1 , $2,4,8$ and $24 \mathrm{~h}$. Reaction products were analyzed by high performance anion-exchange chromatography (HPAEC). Sucrose was hardly hydrolyzed. In the reaction mixture of 1-kestose and the enzyme, fructose and sucrose were produced (Figure 4A). When the enzyme was incubated with nystose, fructose and 1-kestose were produced (Figure 4B) and sucrose was also produced by prolonged incubation. A small amount of transferase activity was detected by prolonged incubation of 1-kestose and

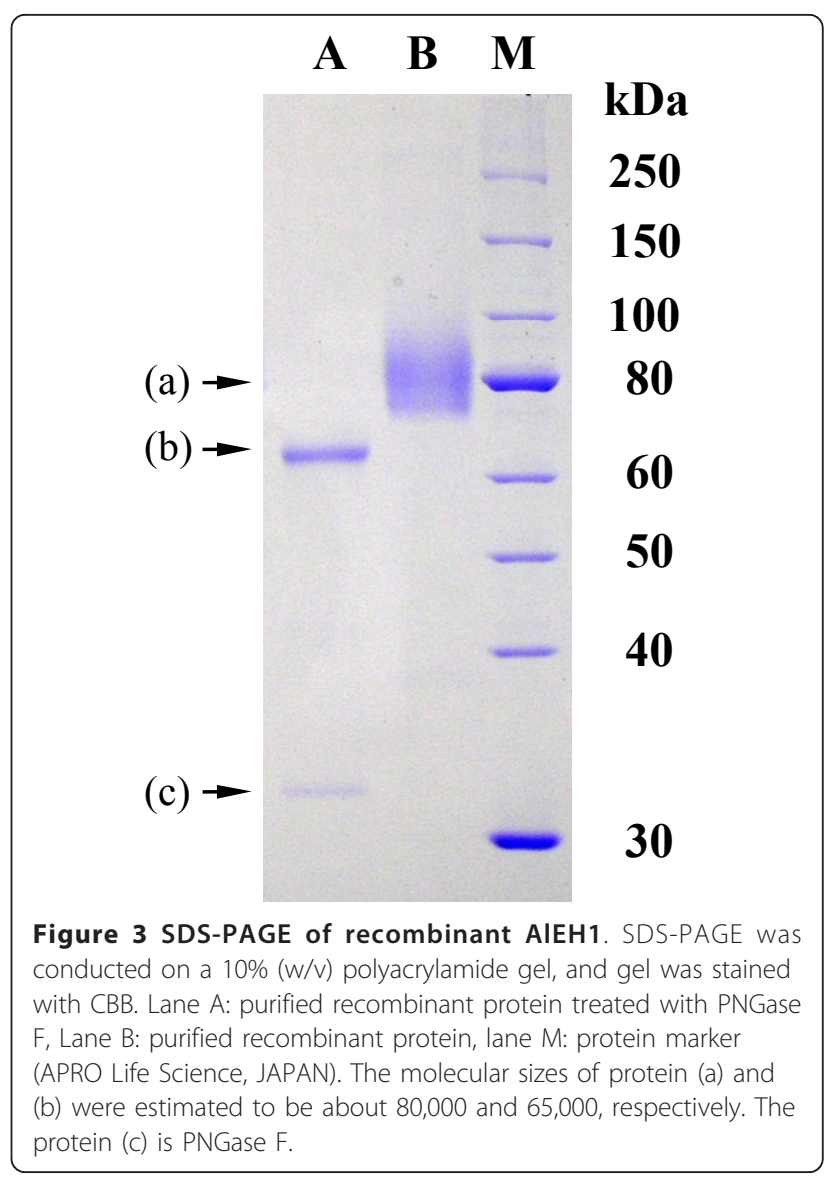

nystose, from which nystose and fructosylnystose were produced, respectively. In reaction mixtures with inulin, fructose was produced (Figure $4 \mathrm{C}$ ). IOS was not produced. These results showed that the enzyme is capable of degrading each substrates via an exo-type of cleavage, releasing terminal fructosyl residues as well as 1-FEHs from other plants [16-18].

To examine the substrate specificity of the recombinant enzyme, the enzyme was incubated with several saccharides (Table 4). Sucrose, neokestose, 6-kestose and high DP levan were hardly hydrolyzed. The recombinant 1 -FEH showed activity against $\beta-2,1$ type fructans such as 1-kestose, nystose, fructosylnystose and inulin. From these results, the recombinant enzyme was 1 -FEH and was not $\beta$-fructofuranosidase or 6 -FEH. Therefore, aleh1 encoded a 1-FEH.

The recombinant 1-FEH hydrolyzed inulotriose 2.5 times slower than 1-kestose although they have $\beta-2,1$ fructofuranosyl linkages.

When the recombinant 1-FEH was incubated for 0,1 and $24 \mathrm{~h}$ with a sugar extract from burdock roots that had been stored in soil for six months (Figure 5), the peak areas of high DP fructan were decreased whereas those of fructose and sucrose were increased. In the reaction 
Table 2 Summary of purification procedures of recombinant AIEH1.

\begin{tabular}{cccccc}
\hline & Total protein $(\mathbf{m g})$ & Total activity $(\mathbf{U})$ & Specific activity $(\mathbf{U} / \mathbf{m g})$ & Recovery (\%) & Purification (-fold) \\
\hline Supernatant & 1,027 & 1,813 & 1.765 & 100 & 1 \\
DEAE-Sepharose CL-6B & 55.3 & 1,003 & 18.1 & 55.4 & 10.3 \\
Toyopearl HW-55S & 17.3 & 469.5 & 27.1 & 25.9 & 15.4 \\
Toyopearl HW-55S & $5.9^{*}$ & 433.2 & 73.4 & 23.9 & 41.6 \\
\hline
\end{tabular}

*In final purification step, proteins were measured as described by lowry et al.

mixture of sugar extracts of stored burdock and the recombinant 1-FEH, a decrease in the peak area of inulobiose was observed to be slower than those of other IOS. The reason for slight decrease of the inulobiose might be due to the low activity against inulobiose as shown in Table 4.

Recently, we have reported the variation of total FOS, total IOS and inulin in burdock roots stored at different temperature [24]. During storage in $0^{\circ} \mathrm{C}$, increase in FOS derived from the hydrolysis of inulin was observed. Moreover, we suggested that the increase of IOS would likely be due to its synthesis by fructosyltransfer from 1-kestose to accumulated fructose and elongated fructose oligomers which can act as acceptors for 1-FFT. The recombinant protein of aleh1 showed 1-FEH activity, and produced fructose from sugars of burdock root, fructooligosaccharides and inulin. Therefore, aleh 1 may be encoding the enzyme involved in hydrolysis of inulin and oligosaccharides, and also in provision of fructose as an acceptor for biosynthesis of IOS by 1-FFT in roots of stored burdock. Further study on the expression of aleh1 in burdock roots during storage at different temperatures is needed for elucidation of the regulation of inulin degradation in burdock roots.

\section{Conclusion}

In this study, we described cloning aleh1 encoding edible burdock fructan 1-exohydrolase and characterization of the recombinant protein of aleh1 expressed in Pichia pastoris. The purified recombinant protein of aleh1 showed 1-FEH activity which released fructose from 1-kestose, nystose, fructosylnystose, inulin and sugars extracted from burdock root, but did not show endo-inulinase activity which produced IOS from inulin. Therefore, aleh1 may be encoding the enzyme not only involved in hydrolysis of inulin but also in provision of fructose as an acceptor for biosynthesis of IOS by 1-FFT in roots of stored burdock.

Table 3 Effects of pH and temperature on 1-FEH activity from recombinant AIEH1

\begin{tabular}{lc}
\hline Optimal pH & 5.8 \\
pH-stability & $5.5 \sim 9.0$ \\
Temperature-stability $\left({ }^{\circ} \mathrm{C}\right)$ & $\leqq 40$ \\
\hline
\end{tabular}

\section{Experimental}

\section{Plant materials}

Edible burdock roots (Arctium lappa L.) were freshly harvested in November from an experimental field of the Makubetsu Agricultural Co-operative, Hokkaido, Japan and then stored in soil $1 \mathrm{~m}$ deep underground until May. After washing with water the roots were stored at $-80^{\circ} \mathrm{C}$ until use.

\section{Substrates}

Saccharides as substrates were prepared as follows. Crystalline 1-kestose [3a: $1^{\mathrm{F}}-\beta$-D-fructofuranosylsucrose, 1 -kestotriose] and nystose [4a: $1^{\mathrm{F}}(1-\beta \text {-D-fructofuranosyl })_{2}$ sucrose, 1, 1-kestotetraose] were prepared from sucrose using Scopulariopsis brevicaulis $\beta$-fructofuranosidase [31]. The standards fructosylnystose, $6 \mathrm{a}, 7 \mathrm{a}$ and $8 \mathrm{a}\left[1^{\mathrm{F}}(1-\beta-\mathrm{D}\right.$ fructofuranosyl $)_{m}$ sucrose, $\left.m=3,4,5,6\right]$ were prepared from Jerusalem artichoke tubers in our laboratory. Sugar extract of burdock roots were prepared from the roots stored for six months [23]. Inulobiose and inulotriose were prepared from stored burdock roots [23]. Sucrose and inulin were purchased from Wako Pure Chemicals Industries (Osaka, Japan). Neokestose was prepared from asparagus roots as described previously [32].

\section{Measurement of enzyme activity}

A reaction mixture consisted of $25 \mu \mathrm{l}$ of enzyme in $10 \mathrm{mM}$ sodium phosphate buffer ( $\mathrm{pH}$ 6.5), $50 \mu \mathrm{l}$ of $200 \mathrm{mM}$ 1-kestose in distilled water, $25 \mu \mathrm{l}$ of $100 \mathrm{mM}$ sodium phosphate buffer ( $\mathrm{pH} 5.8$ ) and a small amount of toluene was incubated at $30^{\circ} \mathrm{C}$. The reaction was stopped by boiling for $3 \mathrm{~min}$. One unit of 1-FEH activity was defined as the amount of enzyme which produced $1 \mu \mathrm{mol}$ of fructose per min under the above reaction conditions. For analysis of reaction products, HPAEC was done on a DX500 chromatograph (Dionex, USA) with a CarboPac PA-1 anion exchange column (Dionex, USA) and a pulsed amperometric detector (PAD) as described previously [32]. The gradient was established by mixing eluent A (150 mM NaOH) with eluent B (500 mM acetate- $\mathrm{Na}$ in $150 \mathrm{mM} \mathrm{NaOH}$ ) in two ways. System I: 0-1 min, $25 \mathrm{mM}$; 1-2 $\mathrm{min}, 25-50 \mathrm{mM}$; 2-20 min, 50-200 mM, 20-22 min, $500 \mathrm{mM}$; 22-30, 25 mM. System II: 0-1 $\mathrm{min}, 25 \mathrm{mM}$; $1-2 \mathrm{~min}, 25-50 \mathrm{mM}$; 2-14 $\mathrm{min}$, 50-500 mM, 14-22 min, $500 \mathrm{mM}$; 22-30, $25 \mathrm{mM}$. The 


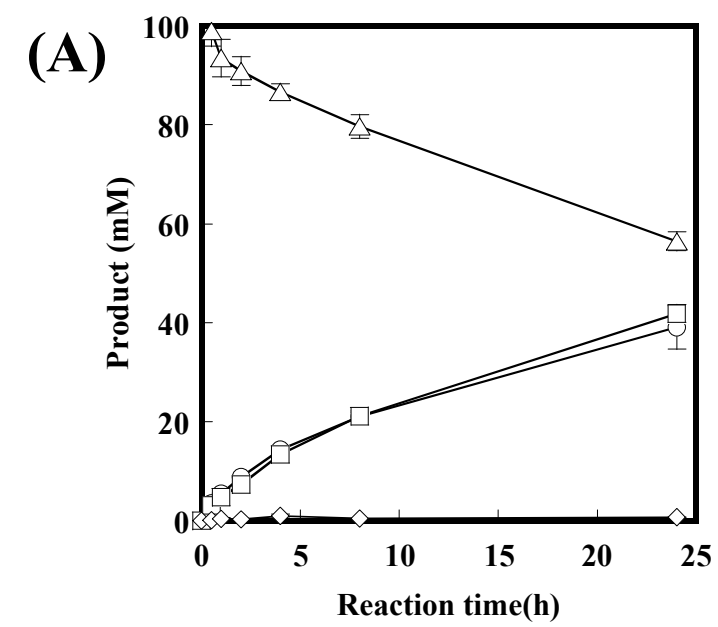

(B)

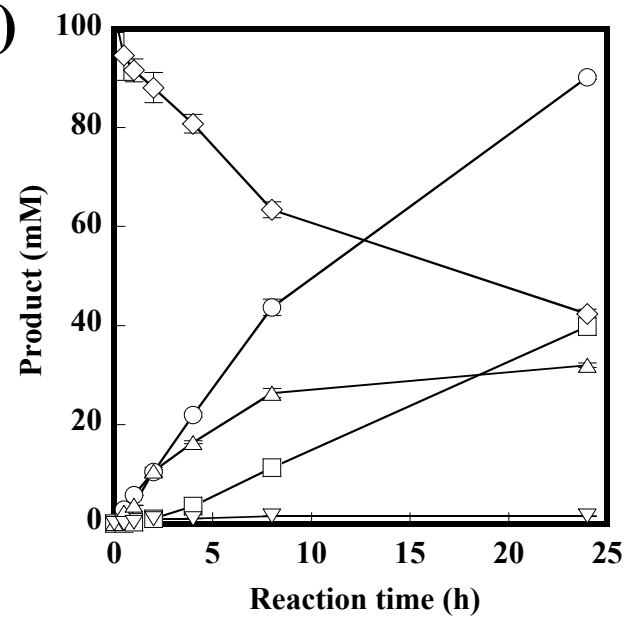

(C)

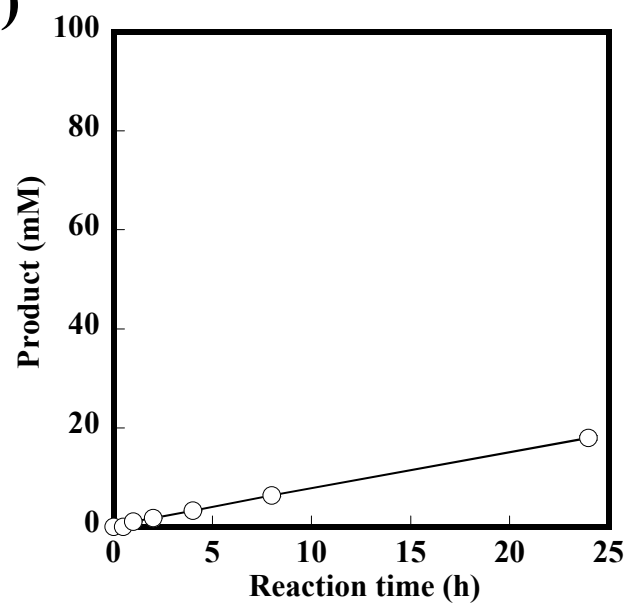

Figure 4 Time courses of saccharides formed from $100 \mathrm{mM}$ 1-kestose (A), nystose (B) or $5 \%$ inulin (C) by purified recombinant AIEH1. Symbols of circle, square and triangle indicate fructose, sucrose and 1-kestose, respectively. Symbols of diamond and inverted triangle indicate nystose and fructosylnystose, respectively. Data are means of 3 replications. Standard deviation indicated with bars.
Table 4 Substrate specificity of recombinant AIEH1.

\begin{tabular}{ccc}
\hline Substrate & DP & Relative activity \\
\hline Sucrose & 2 & 0.2 \\
Inulobiose & 2 & 12 \\
Inulotriose & 3 & 41 \\
1-kestose & 3 & 100 \\
6-kestose & 3 & 2 \\
Neokestose & 3 & 7 \\
Nystose & 4 & 66 \\
Fructosylnystose & 5 & 97 \\
Inulin & & 42 \\
Levan & & 0 \\
\hline
\end{tabular}

Relative activity is expressed as the percentage of the activity with 1-kestose. Final concentration of each substrate in reaction mixture is $10 \mathrm{mM}$ except for levan.

Concentration of the levan in reaction mixture is $0.5 \%$.

established gradient of mixing eluent $A$ with eluent $B$ was: 0-1 $\min , 95 \%$ A-5\% B; 1-2 min, $80 \%$ A-20\% B; $2-20$ min, $60 \%$ A- $40 \%$ B; $20-22$ min, $100 \%$ B, $22-30$ min, $95 \%$ A-5\% $B$. The flow rate through the column was $1.0 \mathrm{~mL} / \mathrm{min}$. The applied PAD potentials for E1 $(400 \mathrm{~ms})$, E2 $(200 \mathrm{~ms})$ and E3 (400 ms) were $0.05,0.75$ and $-0.15 \mathrm{~V}$, respectively, and the output range was $1 \mu \mathrm{C}$ ).

In the experiment for estimation of optimum $\mathrm{pH}$, McIlvaine buffers with a $\mathrm{pH}$ range 3.0-8.0 were used. The reaction was stopped by addition of $900 \mu \mathrm{l}$ of $150 \mathrm{mM}$ sodium hydroxide. For $\mathrm{pH}$-stability profiles, the mixture of $25 \mu \mathrm{l}$ of Britton Robinson buffer with a $\mathrm{pH}$ range 3.0-9.0 and $25 \mu \mathrm{l}$ of purified enzyme solution was kept at $4^{\circ} \mathrm{C}$ for $24 \mathrm{~h}$, and then the mixture was adjusted to $\mathrm{pH} 5.8$, and incubated with $100 \mathrm{mM} \mathrm{1-kestose}$ at $30^{\circ} \mathrm{C}$ for $30 \mathrm{~min}$. The reaction was stopped in a boiling water bath for $3 \mathrm{~min}$. For temperature stability profiles, enzyme solutions were pre-incubated with $0.1 \mathrm{M}$ sodium phosphate buffer ( $\mathrm{pH} 5.8$ ) for $15 \mathrm{~min}$ at 4, 30, 40,50 or $60^{\circ} \mathrm{C}$, and then the pre-incubated solution was cooled to $0^{\circ} \mathrm{C}$, and then the mixtures were incubated with 1 -kestose at $30^{\circ} \mathrm{C}$ for $30 \mathrm{~min}$. All the experiments were done in duplicate.

\section{Quantitative determination of proteins}

Proteins were determined by measuring absorbance at $280 \mathrm{~nm}$ with reference to $\mathrm{E}^{1 \%}$ (extinction coefficient) = 9.38 in aldolase [33]. The concentration of purified protein was measured by the method described by Lowry et al [34].

\section{SDS-polyacrylamide gel electrophoresis (PAGE)}

SDS-PAGE was conducted according to the method of Laemmli [35]. Proteins in the gel were stained with Coomassie Brilliant Blue R-250. 


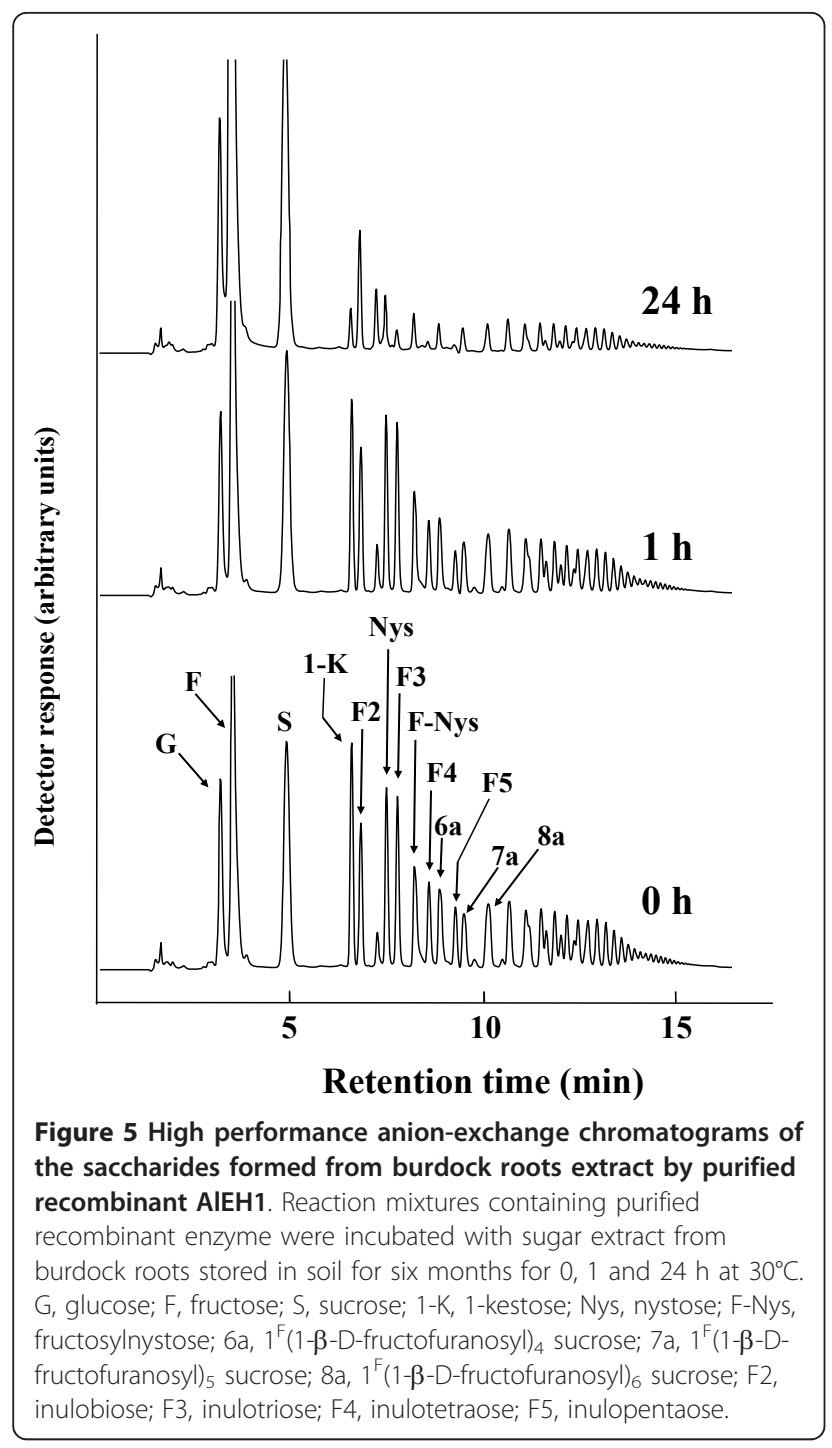

To estimate molecular mass of polypeptide of recombinant protein, deglycosylated recombinant protein was prepared by PNGase F (NEB) as described in the protocol.

\section{Molecular cloning of 1-FEH from edible burdock}

From $1.0 \mathrm{~g}$ of edible burdock roots powder, which were ground in liquid nitrogen, total RNA was prepared using RNeasy Plant Mini Kit (Qiagen, USA). The first strand cDNA was synthesized, using SuperScript III First-Strand Synthesis System for RT-PCR (Invitrogen, USA). The cDNA was used for degenerate PCR and RACE as template. Degenerate PCR was done using a primer set of Dp-A and Dp-C, which were designed according to amino-acid sequences of FEHs from other plants. The PCR consisted of an initial 2 min denaturation step $\left(94^{\circ} \mathrm{C}\right)$ followed by 35 cycles of $94^{\circ} \mathrm{C}$ for $30 \mathrm{~s}$ (denaturation), $50^{\circ} \mathrm{C}$ for $30 \mathrm{~s}$ (annealing) and $72^{\circ} \mathrm{C}$ for
$1 \mathrm{~min}$ (extension) and then a final extension at $72^{\circ} \mathrm{C}$ for 7 min. The PCR was done using Blend Taq polymerase (Toyobo, Japan). The PCR product was subcloned in pGEM-T plasmid, selected in Escherichia coli DH5 $\alpha$ cells (Toyobo, Japan). The plasmid was purified by GenElute Plasmid Mini-Prep Kit (Sigma Aldrich, USA), and its insert DNA was sequenced. The insert was denoted as DegeEHa.

On resulting DNA sequence of DegeEHa, gene-specific primers (5Ra-EHa and 3Ra-EHa) were designed, and used for 5' and 3' RACE to amplify the 5'- and 3'-flanking regions of DegeEHa. RACE was done using the Gene Racer Kit (Invitrogen, USA). The 5' and 3' RACE consisted of an initial 2 min denaturation step $\left(94^{\circ} \mathrm{C}\right)$ followed by 35 cycles of $94^{\circ} \mathrm{C}$ for $15 \mathrm{~s}, 63^{\circ} \mathrm{C}$ for $30 \mathrm{~s}$ and $68^{\circ} \mathrm{C}$ for $70 \mathrm{~s}$ and then a final step at $68^{\circ} \mathrm{C}$ for $10 \mathrm{~min}$. The 5' and 3' RACE were done using KOD plus (Toyobo, Japan). After an adenine residue was attached to the RACE products by A-addition kit (Qiagen, USA), these products were subcloned into pGEM-T vector, and then its insert DNA was sequenced.

Gene-specific primers (EHa-FwA and EHa-RvI) were designed from the DNA sequences of the 5' and 3' RACE products, and subjected to PCR to amplify the DNA corresponding to the open reading frame of target gene. The PCR consisted of an initial 2 min denaturation step $\left(94^{\circ} \mathrm{C}\right)$ followed by 35 cycles of $94^{\circ} \mathrm{C}$ for $15 \mathrm{~s}$, $50^{\circ} \mathrm{C}$ for $30 \mathrm{~s}$ and $68^{\circ} \mathrm{C}$ for $1.5 \mathrm{~min}$ and then a final step at $68^{\circ} \mathrm{C}$ for $10 \mathrm{~min}$. The amplified DNA fragments named PsEHa were sequenced. Full length cDNA was compiled by overlapping the sequences of PsEHa and RACE PCR products. The full length cDNA was named aleh1. Oligonucleotide sequences used for the cloning procedures are listed in Table 1 . The nucleotide sequence of full length cDNA has been submitted to GenBank, EMBL and DDBJ (AB611034).

\section{Expression of recombinant proteins in a methylotrophic Yeast}

The isolated cDNA, named aleh1 was expressed in the methylotrophic yeast Pichia pastoris with the secretory expression vector pPICZ $\alpha \mathrm{B}$ (EasySelect Pichia Expression Kit, Invitrogen, USA). To construct expression plasmids named pPic_aleh1, a DNA fragment containing a gene sequence of aleh1 corresponding to the mature protein was amplified by PCR using EHa-EcoRI.Q34 and EHa-XbaI as primers. These primers also had recognition sequences for EcoRI and XbaI incorporated in forward and reverse primers, respectively (Table 1 ). The PCR condition was 1 cycle of $94^{\circ} \mathrm{C}$ for $2 \mathrm{~min}, 30$ cycles of $94^{\circ} \mathrm{C}$ for $30 \mathrm{~s}, 52^{\circ} \mathrm{C}$ for $30 \mathrm{~s}$ and $68^{\circ} \mathrm{C}$ for $1.5 \mathrm{~min}$, followed by 1 cycle of $68^{\circ} \mathrm{C}$ for $7 \mathrm{~min}$ using KOD plus and PsEHa as template DNA. The PCR products were digested with EcoRI and $X b a I$ followed by ligation into a 
pPICZ $\alpha$ B plasmid vector. The resulting plasmid pPic_aleh1 carries a Zeocin resistance gene and contains a gene sequence of aleh 1 corresponding to the mature protein in frame behind the $\alpha$-factor signal sequence. The pPic_aleh1 was sequenced to ensure no alteration of sequence in comparison with that of original aleh1.

Transformation and cultivation of P. pastoris were performed according to the instructions of the manufacturer with minor modification. P. pastoris $\mathrm{X}-33$ was transformed with $20 \mu \mathrm{g}$ of the SacI-linearized vectors by electroporation, and transformants were selected on YPDS (yeast extract pepton dextrose sorbitol)-Zeocin agar plates. A freshly prepared single colony was inoculated in $5 \mathrm{ml}$ of BMGY (buffered glycerol-complex medium, $\mathrm{pH}$ 6.0), and cells were grown at $29^{\circ} \mathrm{C}$ in a shaking incubator at $200 \mathrm{rpm}$ for $24 \mathrm{~h}$. The cells were collected by centrifugation. The resuspended cell pellet was adjusted to an $A_{600}$ of 1.0 with $15 \mathrm{ml}$ of induction medium (buffered methanol-complex medium, BMMY, pH 6.0, containing $2 \%$ methanol) and incubated at $29^{\circ} \mathrm{C}$ for $72 \mathrm{~h}$ under aerobic conditions, adding $300 \mu \mathrm{l}$ of methanol to the culture at intervals of $24 \mathrm{~h}$. The culture was centrifuged and the supernatant was obtained.

\section{Purification of recombinant protein}

All operations throughout the purification were performed at $0-4^{\circ} \mathrm{C}$. The recombinant protein was purified from the supernatant by DEAE Sepharose CL-6B anion exchange chromatography, Toyopearl HW55S hydrophobic chromatography and Toyopearl HW55S gel filtration chromatography. The supernatant $(45 \mathrm{ml})$ was dialyzed for 1 day against the $10 \mathrm{mM}$ sodium phosphate buffer $(\mathrm{pH}$ 6.5). The dialyzate was applied to a column $(1.8 \times$ $17 \mathrm{~cm}$ ) of DEAE-Sepharose CL-6B equilibrated with 10 $\mathrm{mM}$ sodium phosphate buffer ( $\mathrm{pH}$ 6.5). The adsorbed proteins were eluted with a linear gradient of 0-0.5 M sodium chloride in the same buffer. The active fraction was dialyzed overnight against $45 \%$ saturated ammonium sulfate in $10 \mathrm{mM}$ sodium phosphate buffer ( $\mathrm{pH}$ 6.5). The dialyzate was loaded on to a column $(1.8 \times 17 \mathrm{~cm})$ of Toyopearl HW55S equilibrated with the same buffer. The elution was achieved with a linear gradient from $45 \%$ to $0 \%$ saturation of ammonium sulfate in the same buffer. Each active fraction was dialyzed overnight against $50 \mathrm{mM}$ sodium phosphate buffer containing $100 \mathrm{mM}$ sodium chloride ( $\mathrm{pH}$ 6.5). The dialyzate was concentrated to $1.0 \mathrm{ml}$ by ultrafiltration on VivaSpin concentrator cutting off at $30 \mathrm{kDa}$ (Vivascience, U.K.). The concentrated solution was filtered on a column $(2.0 \times 65 \mathrm{~cm})$ of Toyopearl HW55S equilibrated with the same buffer.

\footnotetext{
Abbreviations

FOS: fructooligosaccharides; IOS: inulooligosaccharides; 1-FEH: fructan 1-exohydrolase; 1-FFT: fructan:fructan 1-fructosyltransferase; 1-SST: sucrose: sucrose 1-fructosyltransferase; DP: Degree of polymerization; HPAEC: high
}

performance anion-exchange chromatography; RACE: rapid amplification of cDNA ends.

\section{Acknowledgements}

This work was partially supported by a Grant-in-Aid to Cooperative Research from Rakuno Gakuen University. Rakuno Gakuen University Dairy Science Institute, 2009-3.

\section{Author details}

${ }^{1}$ Department of Food and Nutrition Sciences, Graduate School of Dairy Science Research, Rakuno Gakuen University, 582 Bunkyodai Midorimachi, Ebetsu, 069-8501, Japan. ${ }^{2}$ National Agricultural Research Center for Hokkaido Region, Hitsujigaoka, Sapporo, 062-8555, Japan.

\section{Authors' contributions}

$\mathrm{KU}$ and $\mathrm{Yl}$ collected data of gene sequences and recombinant protein, and contributed to drafting the manuscript. SO, MY and NS generated study design and drafted manuscript. All authors read and approved the final manuscript.

\section{Competing interests}

The authors declare that they have no competing interests.

Received: 9 February 2011 Accepted: 5 April 2011

Published: 5 April 2011

\section{References}

1. Suzuki M: Fructans in the crop production and preservation. In Science and Technology of Fructans. Edited by: Suzuki M, Chatterton NJ. CRC Press, Boca Raton, FL; 1993:227-255.

2. Vijn I, Smeekens S: Fructan: More Than a Reserve Carbohydrate? Plant Physiol 1999, 120:351-360.

3. Edelman J, Jefford $\mathrm{T}$ : The mechanism of fructosan metabolisim in higher plants as exemplified in Helianthus tuberosus. New Phytol 1968, 67:517-531.

4. Shiomi N, Izawa M: Purification and characterization of sucrose:sucrose 1fructosyltransferase from the roots of asparagus (Asparagus officinalis L.). Agr Biol Chem 1980, 44:603-614

5. Koops AJ, Jonker $\mathrm{HH}$ : Purification and characterization of the enzymes of fructan biosynthesis in tubers of Helianthus tuberosus Colombia. II. Purification of sucrose:sucrose 1-fructosyltransferase and reconstitution of fructan synthesis in vitro with purified sucrose:sucrose 1fructosyltransferase and fructan:fructan 1-fructosyltransferase. Plant Physiol 1996, 110:1167-1175.

6. Lüscher M, Erdin C, Sprenger N, Hochstrasser U, Boller T, Wiemken A: Inulin synthesis by a combination of purified fructosyltransferases from tubers of Helianthus tuberosus. FEBS Lett 1996, 385:39-42.

7. Shiomi N: Purification and characterisation of $1^{\mathrm{F}}$-fructosyltransferase from the roots of asparagus (Asparagus officinalis L.). Carbohydr Res 1982, 99:157-169.

8. Koops AJ, Jonker $\mathrm{HH}$ : Purification and characterization of the enzymes of fructan biosynthesis in tubers of Helianthus tuberosus 'Colombia'. I. Fructan:fructan fructosyltransferase. J Exp Bot 1994, 45:1623-1631.

9. Van den Ende W, Van Wonterghem D, Verhaert P, Dewil E, Van Laere A: Purification and characterization of fructan:fructan fructosyltransferase from chicory roots (cichorium intybus L.). Planta 1996, 199:493-502.

10. Chatterton NJ, Harrison PA: Fructan oligomers in Poa ampla. New Phytol 1997, 136:3-10.

11. Bancal P, Carpita NC, Gaudillère JP: Differences in fructan accumulated in induced and field-grown wheat plants: an elongation-trimming pathway for their synthesis. New Phytol 1992, 120:313-321.

12. Bonnett GD, Sims IM, St John JA, Simpson RJ: Purification and characterization of fructans with $\beta-2,1$ glycosidic linkages and $\beta-2,6$ glycosidic linkages suitable for enzyme studies. New Phytol 1994, 127:261-269.

13. Shiomi N: Purification and characterisation of $6^{G}$-fructosyltransferase from the roots of asparagus (Asparagus officinalis L.). Carbohydr Res 1981, 96:281-292.

14. Shiomi N: Properties of fructosyltransferases involved in the synthesis of fructan in Liliaceous plants. J Plant Physiol 1989, 134:151-155. 
15. Ueno K, Onodera S, Kawakami A, Yoshida M, Shiomi N: Molecular characterization and expression of a cDNA encoding fructan:fructan $6^{\mathrm{G}}$ fructosyltransferase from asparagus (Asparagus officinalis). New Phytol 2005, 165:813-824

16. Van den Ende W, Michiels A, De Roover J, Verhaert P, Van Laere A: Cloning and functional analysis of chicory root fructan 1-exohydrolase I (1-FEH): a vacuolar enzyme derived from a cell-wall invertase ancestor? Mass fingerprint of the 1-FEH I enzyme. Plant J 2000, 24:447-456.

17. Van den Ende W, Michiels A, Van Wonterghem D, Clerens S, De Roover J, Van Laere A: Defoliation induces 1-FEH II (fructan 1-exohydrolase II) in witloof chicory roots: cloning and purification of two isoforms (1-FEH lla and 1-FEH Illb). Mass fingerprint of the 1-FEH II enzymes. Plant Physiol 2001, 126:1186-1195.

18. Van den Ende W, Clerens $S$, Vergauwen R, Van Riet $L$, Van Laere A, Yoshida M, Kawakami A: Fructan 1-exohydrolases: $\beta(2,1)$ trimmers during graminan biosynthesis in stems of wheat? Purification, characterization, mass mapping and cloning of two fructan 1-exohydrolase isoforms. Plant Physiol 2003, 131:621-631.

19. Van Riet L, Nagaraj VJ, Van den Ende W, Clerens S, Wiemken A, Van Laere A: Purification, cloning and functional characterization of a fructan 6-exohydrolase from wheat (Triticum aestivum L.). J Exp Bot 2006, 57:213-223.

20. Kawakami A, Yoshida M, Van den Ende W: Molecular cloning and functional analysis of a novel 6\&1-FEH from wheat (Triticum aestivum L.) preferentially degrading small graminans like bifurcose. Gene 2005, 358:93-101.

21. Van den Ende W, Michiels A, De Roover J, Van Laere A: Fructan biosynthetic and breakdown enzymes in dicots evolved from different invertases. Expression of fructan genes throughout chicory development. Scientific World Journal 2002, 2:1281-1295.

22. Abe M, Ueno K, Ishiguro $Y$, Omori T, Onodera S, Shiomi N: Purification, cloning and functional characterization of fructan: fructan 1fructosyltransferase from edible burdock (Arctium lappa L.). J Appl Glycosci 2009, 56:239-246.

23. Ishiguro Y, Ueno K, Abe M, Onodera S, Fukushi E, Benkeblia N, Shiomi N: Isolation and structural determination of reducing fructooligosaccharides newly produced in stored edible burdock. J Appl Glycosci 2009, 56:159-164.

24. Ishiguro Y, Onodera S, Benkeblia N, Shiomi N: Variation of total FOS, total $\mathrm{IOS}$, inulin and their related-metabolizing enzymes in burdock roots (Arctium lappa L.) stored under different temperatures. Postharvest Biol Technol 2010, 56:232-238.

25. Ishiguro Y, Ueno K, Onodera S, Benkeblia N, Shiomi N: Effect of temperatures on inulobiose and inulooligosaccharides in burdock roots during storage. J Food Compost Anal 2010.

26. Henrissat B: A classification of glycosyl hydrolases based on amino-acid sequence similarities. Biochem J 1991, 280:309-316.

27. Reddy VA, Maley F: Identification of an active-site residue in yeast invertase by affinity labeling and site-directed mutagenesis. J Biol Chem 1990, 265:10817-10820.

28. Reddy A, Maley F: Studies on identifying the catalytic role of Glu-204 in the active site of yeast invertase. J Biol Chem 1996, 271:13953-13957.

29. Meng G, Fütterer K: Structural framework of fructosyl transfer in Bacillus subtilis levansucrase. Nat Struct Biol 2003, 10:935-941.

30. Kawakami A, Yoshida M: Molecular characterization of sucrose:sucrose 1fructosyltransferase and sucrose:fructan 6-fructosyltransferase associated with fructan accumulation in winter wheat during cold hardening. Biosci Biotechnol Biochem 2002, 66:2297-2305.

31. Takeda H, Sato K, Kinoshita S, Sasaki H: Production of 1-kestose by Scopulariopsis brevicaulis. J Ferment Bioeng 1994, 77:386-389.

32. Shiomi N: Structure of fructopolysaccharide (asparagosin) from roots of asparagus (Asparagus officinalis L.). New Phytol 1993, 123:263-270.

33. Babul J, Stellwagen E: Measurement of protein concentration with interferences optics. Anal Biochem 1969, 28:216-221.

34. Lowry OH, Rosebrough NJ, Farr AL, Randall RJ: Protein measurement with the folin phenol reagent. J Biol Chem 1951, 193:265-275.

35. Laemmli UK: Cleavage of structural proteins during the assembly of the head of bacteriophage T4. Nature 1970, 227:680-685.
doi:10.1186/1752-153X-5-16

Cite this article as: Ueno et al:: Cloning and functional characterization of a fructan 1-exohydrolase (1-FEH) in edible burdock (Arctium lappa L.). Chemistry Central Journal 2011 5:16.

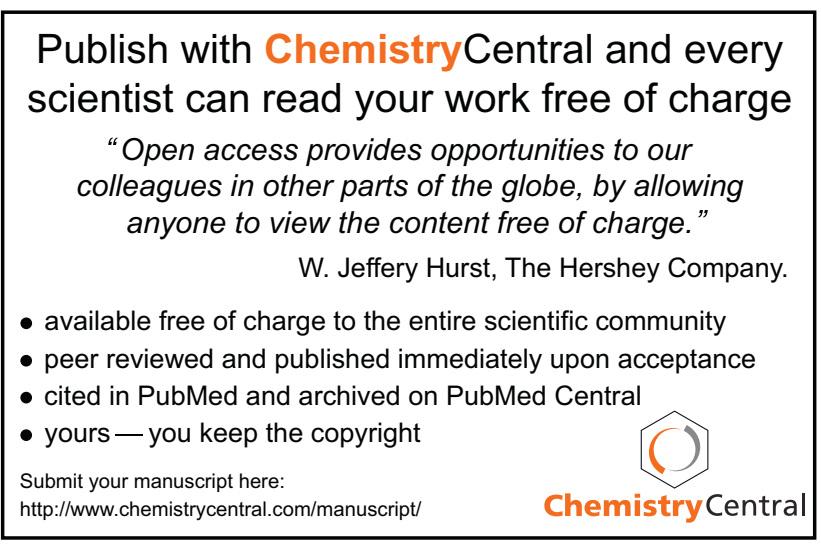

